\title{
A comparative analysis of risk assessment techniques from the risk management perspective
}

\author{
Crina Maria Barb $^{1, *}$, and Daniel Nicolae Fita ${ }^{1}$ \\ ${ }^{1}$ University of Petroşani, Faculty of Mines, 332006 Petroşani, Romania
}

\begin{abstract}
During the last decade, a major concern for Romanian Occupational Health and Safety (OHS) professionals and scholars raised in relation to risk assessment methods and techniques. As well documented in literature, the risk assessment is the basic step in the occupational health and safety risk management process. Risk assessment can be achieved at different levels according to the purpose of the analysis, according to the information, data and resources available. The aim of this paper is to perform a critical - comparative analysis of various worldwide applied methods, in order to establish their feasibility for further studies in the field of electrical safety. The paper gives an accurate comparative presentation in quantitive and qualitative terms of deterministic, probabilistic and combined methods. Furthermore, a detailed description of failure mode, effects and criticality analysis (AMDEC) technique and a SWOT (Strength, Weakness, Opportunity and Threat) analysis is performed. Conclusions are drawn and recommendations made, targeting the applicability of investigated methods for electrical safety activities from the risk management perspective.
\end{abstract}

\section{Introduction}

Risk management facilitates a structured and systematic approach to process of decisionmaking [1]. The value and strength of the risk management approach resides in the fact that it combines various evaluation and consultation techniques and integrates them into a whole that gives consistency to the decision-making process (Fig. 1).

Risk management is a systematic and rigorous process of identification, analysis, planning, control and communication of risks. According to SR EN 31000: 2010 [2], risk analysis is a stage of the risk management process, as shown in Figure 1. Risk management involves the analysis of the internal medium (strengths and weaknesses) and the analysis of the external medium (identifying threats and opportunities) in the organization where the activity takes place. If traditional approaches to risk management were centred predominantly on actions to counteract it, modern methods promote actions of anticipation, simulation, risk prediction, which decrease the reactive function and amplify the preventive

* Corresponding author: crina barb@yahoo.com 
function [3]. The risk has to be understood in terms of "opportunity," in order to properly capitalize on unpredictable situations [3].

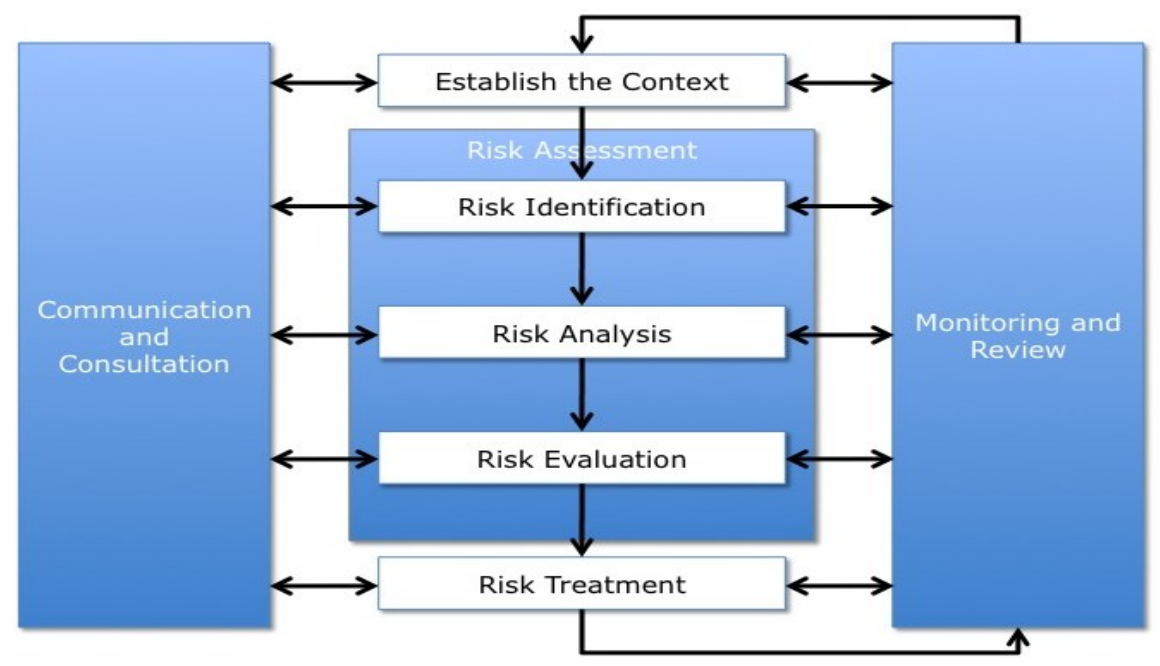

Fig. 1. The standard risk management process

The risk assessment can be done with varying degrees of depth and detail using one or several methods, from simple to complex ones. The form of assessment and its outcome must be consistent with the risk criteria developed as part of the context establishment. There have been developed numerous risk assessment techniques. The selection of techniques may be influenced by various factors such as: availability of information, data and resources. The activity known as risk analysis involves the complete acquisition of the constructive and functional characteristics of the objective or of the process of protection, as well as the systematic use of data and information gathered for the recognition of specific threats. This risk analysis is carried out at different levels of risk detail, of information, of purpose of the analysis, of available resources and data. In the practice of risk analysis, the published literature mentions a long list of methods and techniques from which specialists choose those that best fit the objectives and processes that need protection.

Organizations may use different risk assessment methods as part of a global strategy to deal with various hazards or activities. The complexity of the occupational risk assessment method does not depend on the size of the organization, but on the dangers associated with the activities of each organization [4].

\section{Comparison of risk analysis methods}

Based on the published literature, the documentary study on risk analysis methods and diagnostics of security systems illustrates this classification in Table 1. Risk assessment techniques should be selected on the basis of applicable factors such as [5]:

- the type and range of risks assessed;

- objectives of the study: the objectives of the risk assessment will exert a direct impact on the techniques used;

- degree of expertise, human resources and other resources needed: a well-structured method can deliver better results than a sophisticated procedure, as long as it meets the objectives of the evaluation; 
- the needs of the decision factors: in some cases, a high level of detail is required to make a good decision and in other cases a more general understanding is sufficient;

- the possible magnitude of the consequences: the decision on the depth of risk assessment must reflect the initial perception of the consequences.

In the risk analysis process we distinguish two major categories: the qualitative risk analysis and the quantitative risk analysis. The results of the qualitative risk analysis are less accurate as the results are rather indicative than precise. If these results are not satisfactory, risk management also provides a quantitative analysis.

This quantitative analysis refers to the calculation of the level impact of a risk. If the risk analyst cannot assign an exact probability of such an event, he may instead calculate the amount of loss or depreciation.

Table 1. Synthesis of risk analysis methods in quantitative and qualitative terms.

\begin{tabular}{|c|c|c|}
\hline $\begin{array}{l}\text { Risk Analysis } \\
\text { Methods }\end{array}$ & Quantitative & Qualitative \\
\hline $\begin{array}{l}\text { Deterministic } \\
\text { methods }\end{array}$ & $\begin{array}{l}\text { - } \quad \text { Hazard Identification and Ranking } \\
\text { - } \quad \text { Accident Hazard Index } \\
\text { - } \quad \text { Dow's Chemical Exposure Index } \\
\text { Method of calculating and assessing } \\
\text { the potential of risk }\end{array}$ & $\begin{array}{ll}- & \text { Workload Analysis } \\
\text { - } & \text { Preliminary Risk Analysis } \\
\text { - } & \text { Action Error Analysis } \\
\text { - } & \text { Failure mode and effect } \\
& \text { analysis } \\
\text { - } & \text { 'What if?' Analysis } \\
\text { - } & \text { Checklists } \\
\end{array}$ \\
\hline $\begin{array}{l}\text { Probabilistic } \\
\text { methods }\end{array}$ & $\begin{array}{ll}\text { - } & \text { Fault Tree Analysis } \\
\text { - } & \text { DEFI Method (injection of defects) }\end{array}$ & $\begin{array}{l}\text { - Structural Reliability Analysis } \\
\text { - Delphi Technique }\end{array}$ \\
\hline $\begin{array}{l}\text { Combined } \\
\text { methods }\end{array}$ & $\begin{array}{l}\text { - } \quad \text { Optimal Risk Assessment } \\
\text { - The "butterfly loop" method } \\
\text { - } \quad \text { Failure mode, effects and criticality } \\
\text { analysis } \\
\text { - } \quad \text { Rapid Ranking }\end{array}$ & $\begin{array}{ll}\text { - } & \text { Reliability Block Diagram } \\
\text { - } & \text { Level of Protection Analysis }\end{array}$ \\
\hline
\end{tabular}

There are three classes of risk analysis methods: deterministic, probabilistic and combined. The employment of a risk analysis method brings the advantage of using performance tools recognized in the published literature. Risk assessment is a complex study based on a series of quantitative and qualitative analysis methods.

Owing to their systematic nature, each of these methods allows the realization of at least one of the following objectives: the identification of the causes and of the potential consequences of events related to the operation of industrial systems; the estimation of risk in terms of probability and severity; the highlighting of existing security barriers, or of the ones that should be applied for a reduction of the risk. [6] .Classical methods of analysis share some common advantages [6]:

- systemic character: allows the methodical approach of the various dangerous situations, of the undesirable events, as well as of the generating causes and their consequences;

- valorisation of the multidisciplinary knowledge: it all applies in the context of complex analysis teams, representing tools for exchange of information and communication between people, professions and different viewpoints;

- complementarity: various methods can be applied within a single approach, each being selected for a segment of the system or for a stage of the analysis, depending on the objectives pursued.

Table 2 summarizes the comparative study of the characteristics of the main analysis and assessment methods of risks. 
Table 2. Comparison between the characteristics of risk analysis and assessment methods [6].

\begin{tabular}{|c|c|c|c|c|c|}
\hline $\begin{array}{c}\text { Analysis } \\
\text { method }\end{array}$ & $\begin{array}{l}\text { Type of } \\
\text { industry }\end{array}$ & Objective & $\begin{array}{c}\text { Integration } \\
\text { level }\end{array}$ & Notifications & $\begin{array}{l}\text { Tackling } \\
\text { barriers }\end{array}$ \\
\hline $\begin{array}{c}\text { AMDE } \\
\text { (qualitative } \\
\text { determinant) }\end{array}$ & $\begin{array}{l}\text { Technical } \\
\text { systems, } \\
\text { discrete } \\
\text { processes }\end{array}$ & $\begin{array}{l}\text { Detailed } \\
\text { analysis of } \\
\text { failure modes } \\
\text { of components } \\
\text { of a system } \\
\text { and their } \\
\text { consequences }\end{array}$ & Subsystem & $\begin{array}{l}\text { It requires } \\
\text { advanced } \\
\text { decomposition } \\
\text { of subsystems }\end{array}$ & $\begin{array}{l}\text { It does not } \\
\text { quantify }\end{array}$ \\
\hline $\begin{array}{c}\text { AAE } \\
\text { (quantitative } \\
\text { probability) }\end{array}$ & All & $\begin{array}{l}\text { Inductive } \\
\text { analysis: } \\
\text { representation } \\
\text { of the possible } \\
\text { consequences } \\
\text { of an event. } \\
\text { Generally, the } \\
\text { analysis of the } \\
\text { consequences } \\
\text { of the } \\
\text { operation or } \\
\text { non- } \\
\text { functioning of } \\
\text { barriers. }\end{array}$ & Subsystem & $\begin{array}{l}\text { It is useful for } \\
\text { systematic } \\
\text { view and } \\
\text { analysis of the } \\
\text { consequences } \\
\text { of the non- } \\
\text { functioning of } \\
\text { barriers }\end{array}$ & $\begin{array}{l}\text { The events } \\
\text { consist of the } \\
\text { functioning or } \\
\text { non- } \\
\text { functioning of } \\
\text { the control } \\
\text { elements of the } \\
\text { process or of } \\
\text { the security } \\
\text { barriers }\end{array}$ \\
\hline $\begin{array}{c}\text { LOPA } \\
\text { (combined } \\
\text { qualitative) }\end{array}$ & $\begin{array}{l}\text { Process- } \\
\text { based } \\
\text { industries. }\end{array}$ & $\begin{array}{l}\text { Analysis of } \\
\text { risks of an } \\
\text { industrial } \\
\text { system at } \\
\text { various levels } \\
\text { of analysis, } \\
\text { highlighting } \\
\text { the control } \\
\text { means of risk }\end{array}$ & Locality & $\begin{array}{l}\text { It uses ADD } \\
\text { and ADE }\end{array}$ & $\begin{array}{l}\text { Quantitative } \\
\text { approach } \\
\text { based on the } \\
\text { notion of } \\
\text { security } \\
\text { integration } \\
\text { level }\end{array}$ \\
\hline $\begin{array}{c}\text { AMDEC } \\
\text { (combined } \\
\text { quantitative) }\end{array}$ & $\begin{array}{l}\text { Technical } \\
\text { systems, } \\
\text { discrete } \\
\text { processes }\end{array}$ & $\begin{array}{l}\text { Detailed } \\
\text { analysis of } \\
\text { failure modes } \\
\text { of components } \\
\text { of a system } \\
\text { and their } \\
\text { consequences }\end{array}$ & Subsystem & $\begin{array}{l}\text { It requires } \\
\text { advanced } \\
\text { decomposition } \\
\text { of subsystems }\end{array}$ & $\begin{array}{l}\text { It does not } \\
\text { quantify }\end{array}$ \\
\hline
\end{tabular}

The assessment criteria of occupational hazards must be defined according to their scope, nature and timing in order to ensure that they are proactive rather than reactive and that they are used in a systematic manner [7]. Methods of risk analysis and assessment allow identification of hazards and quantification of risks.

There is a large range of risk analysis and assessment methods, characterized by variety in terms of the general approach. Risk assessment can be achieved with varying degrees of complexity using one or several methods from simple to complex ones. The form of assessment and its outcome must meet the risk criteria developed as part of the establishment of the context. 


\section{SWOT (Strength, Weaknesses, Opportunities, Threats) analysis of the AMDEC (Failure mode, effects and criticality analysis) method}

AMDEC (Failure mode, effects and criticality analysis) is an inductive method that allows the systematic study of causes and effects of defects which affect the components of a system (product, machine or process). It is a qualitative method of reliability that permits us to anticipate the risk of defects, the assessment of their consequences and the determination of the causes [8-9]. The method has as its main objective the achievement of quality by a system. AMDEC is an analysis method that attempts to bring together the competences of the workgroups involved in a production process in order to establish a plan of measures with a view to increase the quality of products, processes and production environments.

This method is considered to be a basic tool in the management of projects, maintenance and total quality. The AMDEC technique is generally applicative in order to identify the causes of the failures, the failure modes and the effects of these failures. The selection of a particular technique is conditioned by the data available at the time of analysis [10-11]. The AMDEC method is an extension of the AMDE method, which in addition includes the analysis of criticality by quantifying the effects in terms of probability of occurrence and criticality of any failure mode. The probability of occurrence of failure modes is estimated on the basis of known reliability estimation methods (Table 3).

Table 3. SWOT analysis of the AMDEC method.

\begin{tabular}{|c|c|}
\hline Strength & Opportunities \\
\hline $\begin{array}{l}\text { Particularly applicable to fault modes due to } \\
\text { human factor, equipment, hardware and } \\
\text { software systems and procedures; } \\
\text { It provides results for the development of } \\
\text { monitoring programs by highlighting the key } \\
\text { features to be monitored; } \\
\text { It avoids the need for expensive equipment } \\
\text { changes in operation by identifying early } \\
\text { design problems; } \\
\text { It identifies localized fault modes and } \\
\text { requirements for redundancy or security } \\
\text { systems; } \\
\text { It identifies the component failure modes, its } \\
\text { causes and effects on the system and presents } \\
\text { them in an understandable format. }\end{array}$ & 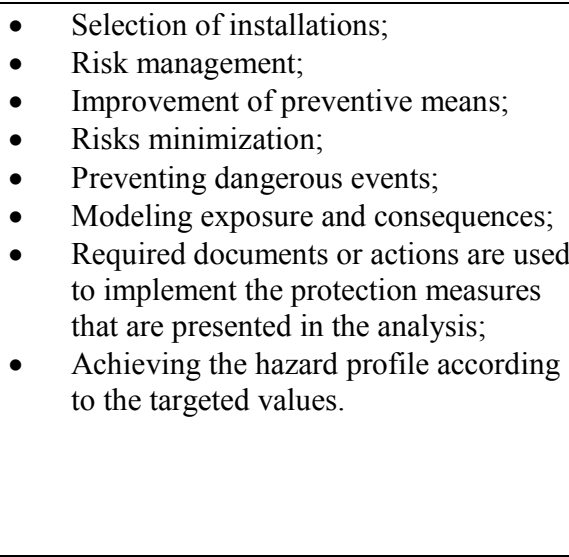 \\
\hline Weaknesses & Threats \\
\hline $\begin{array}{l}\text { - These can only be used to identify the } \\
\text { localized fault modes and not combinations } \\
\text { of fault modes; } \\
\text { Unless the case when they are controlled and } \\
\text { set up accordingly, studies can be time- } \\
\text { consuming and costly; } \\
\text { These can be difficult and annoying for } \\
\text { complex multi-layered systems; } \\
\text { It does not establish the protection / } \\
\text { intervention measures / actions needed to } \\
\text { limit and remove the consequences of a } \\
\text { possible major accident. }\end{array}$ & $\begin{array}{l}\text { It only considers lethal effects on } \\
\text { people; } \\
\text { The possibility that the population does } \\
\text { not understand the outcome of the } \\
\text { estimate; } \\
\text { The likelihood of a major accident } \\
\text { involving loss of life and material } \\
\text { goods; } \\
\text { It does not provide for consideration of } \\
\text { specific prevention barriers to reduce } \\
\text { the likelihood of loss of isolation. }\end{array}$ \\
\hline
\end{tabular}


The estimation of the criticality of the effects is done, in principle, by reference to an established scale. Considering the importance of the method, a SWOT analysis of the AMDEC method was undertaken and the results were centralized in Table 3.

\section{Conclusions}

In order to have the expected importance and effectiveness, risk management must be an integral part of the general management of the system. Technical risk control covers all the methods, means, analyses, procedures and actions applied throughout the entire life cycle of a system in order to eliminate risks or render them acceptable.

Occupational risk assessment should be part of a wider framework that uses the information gathered in order to take decisions on risk responses and monitoring, providing information that has to be reintroduced into the global strategic planning process. Occupational risk assessment must be led by top management.

The purpose of applying the AMDEC method is to identify the corrective actions which must be applied in order to improve a system based on the triplet: cause - failure mode effect. The AMDEC method is extremely effective when it is applied to the analysis of simple failure of the elements leading to the system's global failure. The method is a tool for identifying potential defects and means to limit the effects and the likelihood of production. From the point of view of work safety and health, the analysis of risk assessment methods is useful especially in terms of aggregation of the stages of hazard identification, of prevention and protection measures and of risk assessment.

\section{Results}

The purpose of this paper was to perform a critical comparative analysis of various worldwide applied methods. A detailed description of failure mode, effects and criticality analysis (AMDEC) method was realized.

Also, it was performed a SWOT analysis of the AMDEC technique which is an important tool for identifying potential defects. It was made a comparative presentation in quantitative and qualitative terms of deterministic, probabilistic and combined methods.

Furthermore, this paper presents a general overview of the methods which are used in the risk analysis. The methods of risk analysis are the most frequently used and not very well known at the same time.

\section{References}

1. R.I., Moraru, G.B., Băbuţ, Risk management, Global approach - concepts, principles and structure (Petrosani, Romania, 2009)

2. ASRO SR ISO 31000: 2010, Risk management. Principles and guidelines regarding the implementation (2010)

3. R.I., Moraru, G.B., Băbuţ, Quality - Access to Success J. 11, 4, 50-59 (2010)

4. R.I., Moraru, G.B., Băbuţ, L.I., Cioca, Proc. of the 17th Int. Conf. The Knowledge-Based Organization: Management and Military Sciences, 735-740 (Sibiu, Romania, 2011)

5. SR EN 31010: 2010 Risk management. Risk assessment techniques (2010)

6. M.S., Popescu, Integrated methodology for risk analysis and diagnostics of industrial systems security (Petrosani, Romania, 2015)

7. R.I., Moraru, G.B, Băbuţ, L.I., Cioca, Proc. of the 5th Int. Conf. on Manufacturing Science and Educations - MSE 2011, 2, 363-366 (Sibiu, Romania, 2011)

8. A., Darabont, Evaluation of the security quality of technical equipment (Bucharest, 2001)

9. M., Cioca, L.I., Cioca, 3rd IEEE Int. Conf. on Industrial Informatics, 1560381, 230-233 (2005) 
10. R.I., Moraru, G.B, Băbuţ, L.I., Cioca, Proc. of the 5th International Conf. on Manufacturing Science and Educations - MSE 2011, 2, 363-366 (Sibiu, Romania, 2011)

11. G.B, Băbuţ, R.I., Moraru, Proc. of the 16th Int. Multidisciplinary Scientific GeoConference SGEM 2016: Science and Technologies in Geology, Exploration and Mining 2, 635-642 (Albena, Bulgaria, 2016) 